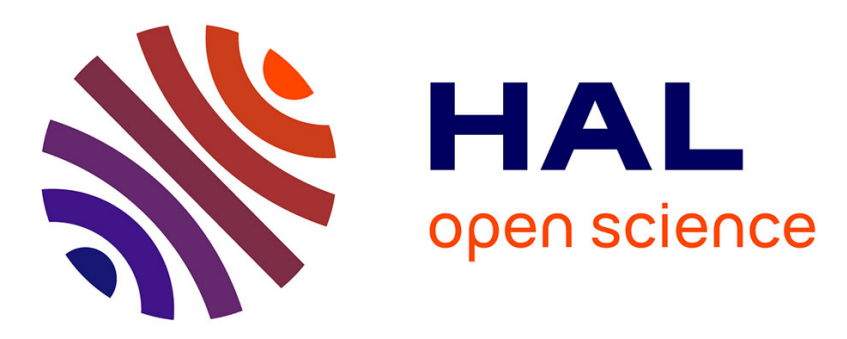

\title{
Incorporation of hydrophobized mineral particles in activated sludge flocs: a way to assess ballasting efficiency
}

G. Defontaine, J. Thormann, B.S. Lartiges, A.G. El Samrani, O. Barres

\section{- To cite this version:}

G. Defontaine, J. Thormann, B.S. Lartiges, A.G. El Samrani, O. Barres. Incorporation of hydrophobized mineral particles in activated sludge flocs: a way to assess ballasting efficiency. Water Science and Technology, 2005, 52 (10-11), pp.177-184. 10.2166/wst.2005.0692 . hal-02284244

\author{
HAL Id: hal-02284244 \\ https://hal.science/hal-02284244
}

Submitted on 11 Sep 2019

HAL is a multi-disciplinary open access archive for the deposit and dissemination of scientific research documents, whether they are published or not. The documents may come from teaching and research institutions in France or abroad, or from public or private research centers.
L'archive ouverte pluridisciplinaire HAL, est destinée au dépôt et à la diffusion de documents scientifiques de niveau recherche, publiés ou non, émanant des établissements d'enseignement et de recherche français ou étrangers, des laboratoires publics ou privés. 


\title{
Incorporation of hydrophobized mineral particles in activated sludge flocs: a way to assess ballasting efficiency
}

\author{
G. Defontaine, J. Thormann, B.S. Lartiges, A.G. Elsamrani, O. Barrès \\ (bruno.lartiges@ensg.inpl-nancy.fr)
}

LEM-INPL-CNRS/University of Nancy - 15 Avenue du Charmois

BP 40- 54501 Vandoeuvre Cedex - France

\begin{abstract}
The role of mineral surface hydrophobicity on attachment to activated sludge flocs was investigated. Fluorite and quartz particles of similar granulometry were hydrophobized by adsorbing sodium oleate and docecylamine chloride, respectively. Mineral hydrophobicity was assessed by flotation expriments. The attachment of particles to microbial flocs was determined by optical microscopy. The results indicate that hydrophobized particles are always better incorporated within activated sludge flocs than non-coated particles. A comparison with Aquatal particles used as sludge ballast reveals that hydrophobized minerals are associated with microbial flocs to the same extent.
\end{abstract}

\section{KEY WORDS}

Activated sludge - ballasting - floc - hydrophobicity

\section{INTRODUCTION}

The overall performance of an activated sludge wastewater treatment process depends primarily on the efficiency of the sludge/treated effluent separation in the secondary clarifier. When poor settling is observed, the settleability of activated sludge flocs can be improved by addition of mineral particles acting as floc ballasting agents (Rasmussen et al., 1996; Vanderhasselt and Verstraete, 1999; Piirtola et al., 1999). However, even though the enhanced sludge settling properties seems to result mainly from an increase in the average density of bacterial aggregates (Rasmussen et al., 1996; Vanderhasselt and Verstraete, 1999), the ballasting performance can not be simply correlated with density and size distribution of minerals added to the sludge (Piirtola et al., 1999). According to Piirtola et al. (1999), the surface characteristics of the mineral material also influence the attachment of minerals to the floc. On the other hand, it has been shown that the attachment of bacteria to activated sludge flocs is clearly correlated with the microbial cell surface hydrophobicity (Zita and Hermansson,1997; Olofsson et al., 1998). Zita and Hermansson also indicated that the surface charge does not appear to be a significant factor in determining bacterial adhesion. Furthermore, floc hydrophobicity has been shown to play an important role in the settling activated sludge flocs (Urbain et al., 1993).

The aim of the present work is then to investigate the role of mineral surface hydrophobicity on attachment with activated sludge flocs. Hydrophobized particles were obtained by coating quartz and fluorite with surfactants. Hydrophobicity was assessed by flotation and incorporation of particles within microbial flocs was determined by optical microscopy.

\section{METHODS}

Sample collection. Activated sludge samples were collected from the aeration tank at the local municipal wastewater treatment plant (Maxeville, France - capacity of 300000 population equivalent). The grab samples, collected in $2 \mathrm{~L}$ polyethylene containers, were transported to the laboratory and used for experiments within $2 \mathrm{~h}$ of collection. Total suspended solid contents were 
determined by drying a $50 \mathrm{~mL}$ centrifuged sample $(3000 \mathrm{~g}$ for $5 \mathrm{~min})$ at $105{ }^{\circ} \mathrm{C}$. The values averaged $3.5 \mathrm{~g} / \mathrm{L}$ during the period of the study. The $\mathrm{pH}$ measurements showed values around 7.2.

Mineral particles. Three types of natural mineral particles were tested for association with activated sludge flocs: fluorite $\mathrm{CaF}_{2}$ (Montroc - France), quartz $\mathrm{SiO}_{2}$ (Madagascar), and Aquatal, a talcchlorite interstratified mineral commercialized by Luzenac Europe as an effective ballasting agent for sludges of poor settleability (Bidault 1996). All particles were slightly ground and sieved to obtain mean particle sizes of $12 \mu \mathrm{m}$ for fluorite, $15 \mu \mathrm{m}$ for quartz, and $10 \mu \mathrm{m}$ for Aquatal. The average densities are 3.3,2.65, and 2.7, respectively. Fluorite presents a positive surface charge around $\mathrm{pH} 7$, whereas Aquatal and quartz are negatively charged at neutral $\mathrm{pH}$.

Hydrophobization of particles. Fluorite and quartz were made hydrophobic by addition of sodium oleate $\left(\mathrm{C}_{17} \mathrm{H}_{33} \mathrm{COONa}\right.$ - MW $304.45 \mathrm{~g} / \mathrm{mol}$ - Critical Micellar Concentration (CMC) $710^{-4} \mathrm{~mol} / \mathrm{L}$ Prolabo) and dodecylamine chloride $\left(\mathrm{C}_{12} \mathrm{H}_{17} \mathrm{NH}_{3} \mathrm{Cl}-\mathrm{MW} 221.82 \mathrm{~g} / \mathrm{mol} \mathrm{CMC}=710^{-3} \mathrm{~mol} / \mathrm{L}-\right.$ CECA S.A.), respectively. The adsorption of oleate on fluorite has been shown to be a very dynamic process with various steady states being achieved according to oleate concentration, $\mathrm{pH}$, solid/liquid ratio, and calcium concentration (Mielczarski et al., 1999). As a consequence, a short equilibration time was selected for fluorite conditioning. A given surfactant concentration (oleate stock solution $=510^{-2} \mathrm{~mol} / \mathrm{l}$ ) was added to a $5 \mathrm{~g} / \mathrm{L}$ fluorite suspension in a $20 \mathrm{~mL}$ vial. After $3 \mathrm{~min}$ of vigorous hand-shaking, the suspension was centrifuged at $5000 \mathrm{rpm}$ for $10 \mathrm{~min}$. Both centrifugate and sediment (air-dried) were recovered. The retention of sodium oleate on fluorite was monitored in two ways: (i) the residual concentration of oleate was measured by colorimetry, (ii) the adsorbed amount on fluorite particles was assessed by infrared reflectance (DRIFT) (Bruker IFS 55). The colorimetry method is based on the determination of residual anionic charge by reaction in alkali solution with cationic copper (II) triethylenetetramine (Gregory 1966). The complex formed is extracted with a 80/20 cyclohexane-isobutanol mixture and the amount of copper associated with the anionic surfactant is determined photometrically (Shimadzu uv-2100) using diethylammonium diethyldithiocarbamate. The adsorbed amount is then obtained by difference. DRIFT measurements were conducted with $70 \mathrm{mg}$ of air-dried fluorite/oleate particles mixed with $370 \mathrm{mg}$ of dried $\mathrm{KBr}$. The amount of oleate was obtained by integrating the bands assigned to the alkyl chain (2922 and $\left.2852 \mathrm{~cm}^{-1}\right)$.

The adsorption isotherm of docecylammonium chloride on quartz particles was previously determined by Doerler (1982). A 2 hour conditioning time was found necessary to reach adsorption equilibrium.

Particle hydrophobization was tested by flotation with a modified Hallimond tube. In this method, $\mathrm{N}_{2}$ micro-bubbles blown through the porous base of a glass tube, carry the floatable hydrophobic particles to the surface. The relative weight percentage of floated particles after a contact time of 10 minutes provides a measurement of surface hydrophobicity.

Incorporation of particles in activated sludge flocs. Addition of particles to activated sludge flocs was carried out in a $1 \mathrm{~L}$ baffled reactor under constant agitation $\left(100 \mathrm{rpm}-\mathrm{G}=135 \mathrm{~s}^{-1}\right)$ for $30 \mathrm{~min}$. Activated sludge was first diluted to a concentration of $500 \mathrm{mg} / \mathrm{L}$ with supernatant obtained from centrifuging the raw sludge at $7000 \mathrm{rpm}$ for $30 \mathrm{~min}$ in $250 \mathrm{~mL}$ bottles (L8-55M Beckman Ultracentrifuge). $20 \mathrm{~mL}$ of the conditioned particle suspension was then added to the diluted sludge to yield a $20 \%$ wt of ballasting agent relative to sludge concentration. Sludge dilution enabled the on-line monitoring of floc size distribution with a Malvern Particle sizer (1.2-600 $\mu \mathrm{m}$ size range). and allowed to check that addition of particles did not modify the floc size. Experimental conditions and set-up were described in a previous study (Chaignon et al., 2002). 
The amount of particles associated with an activated sludge floc was assessed by optical microscopy. The sludge conditioned with particles was sampled at the lower third of the reactor with a wide mouth pipette, placed on a glass slide, and examined with a Nachet NS 400 optical microscope equipped with a Leitz Wild MPS 52 camera. The activated sludge flocs were observed between crossed polarizer and analyzer at a magnification of $x 1250$. Under those conditions, the mineral particles incorporated inside the flocs appear as bright spots within the floc organic matrix (fig. 1). The amount of particles associated with a floc can then be assessed from the exposure time required to take a photograph in spot mode at the center of the floc studied. About 100 flocs, randomly selected, were examined in each experiment. The results are presented as cumulative frequency curves.

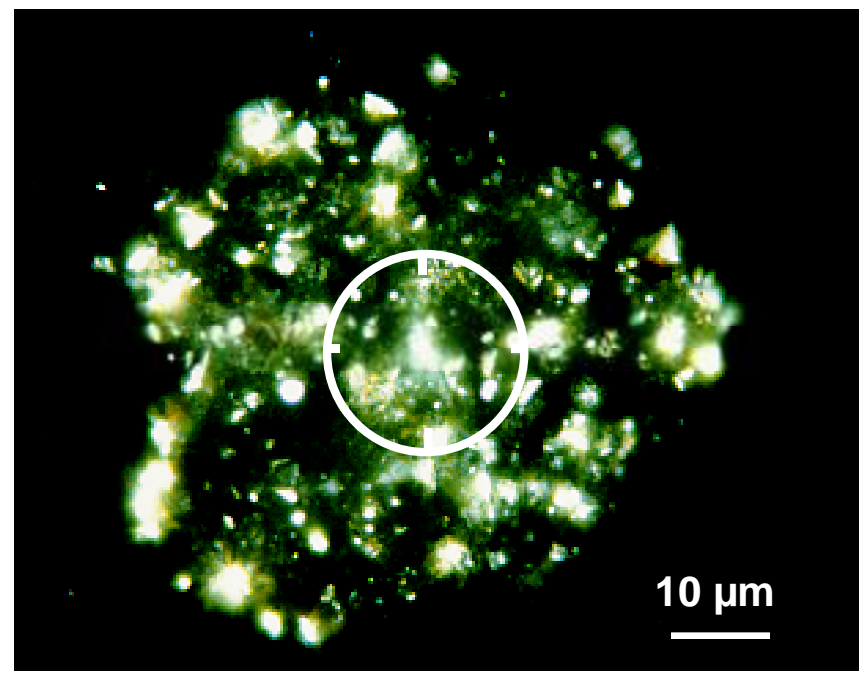

Fig. 1. Micrograph of an activated sludge floc spiked with Aquatal particles between crossed polarizer and analyzer. The white circle indicates the measurement spot.

\section{RESULTS AND DISCUSSION}

Oleate fixation on fluorite. The amount of oleate adsorbed on fluorite determined from the integrated IR area of alkyl chain bands, is presented in figure $2 \mathrm{a}$ as a function of surfactant equilibrium concentration determined by colorimetry. The adsorbed amount steadily increases with surfactant concentration to reach a plateau around a supernant concentration of $510^{-5} \mathrm{~mol} / \mathrm{L}$.

Figure $2 \mathrm{~b}$ shows the amount of oleate adsorbed on fluorite determined by colorimetry. Up to a $10^{-4}$ $\mathrm{mol} / \mathrm{L}$ oleate concentration, the adsorbed amount follows a similar pattern as in figure $2 \mathrm{a}$. However, at higher oleate concentrations, a sharp increase in adsorbed amount is observed. The discrepancy between DRIFT and colorimetric methods in determining the amount of oleated adsorbed on fluorite at high surfactant concentration, can be explained by the formation of a calcium oleate microprecipitates. For oleate concentration greater than, the presence of such precipitates is readily identified by additional peaks in the infrared spectra $510^{-3} \mathrm{~mol} / \mathrm{L}$ (not shown here). In the $10^{-4}-5$ $10^{-3}$ contration range, the discrepancy between both methods could still be explained by the existence of calcium oleate precipitate not detected by colorimetry: due to their small size, such precipitate remains in suspension and is not detected by DRIFT. 

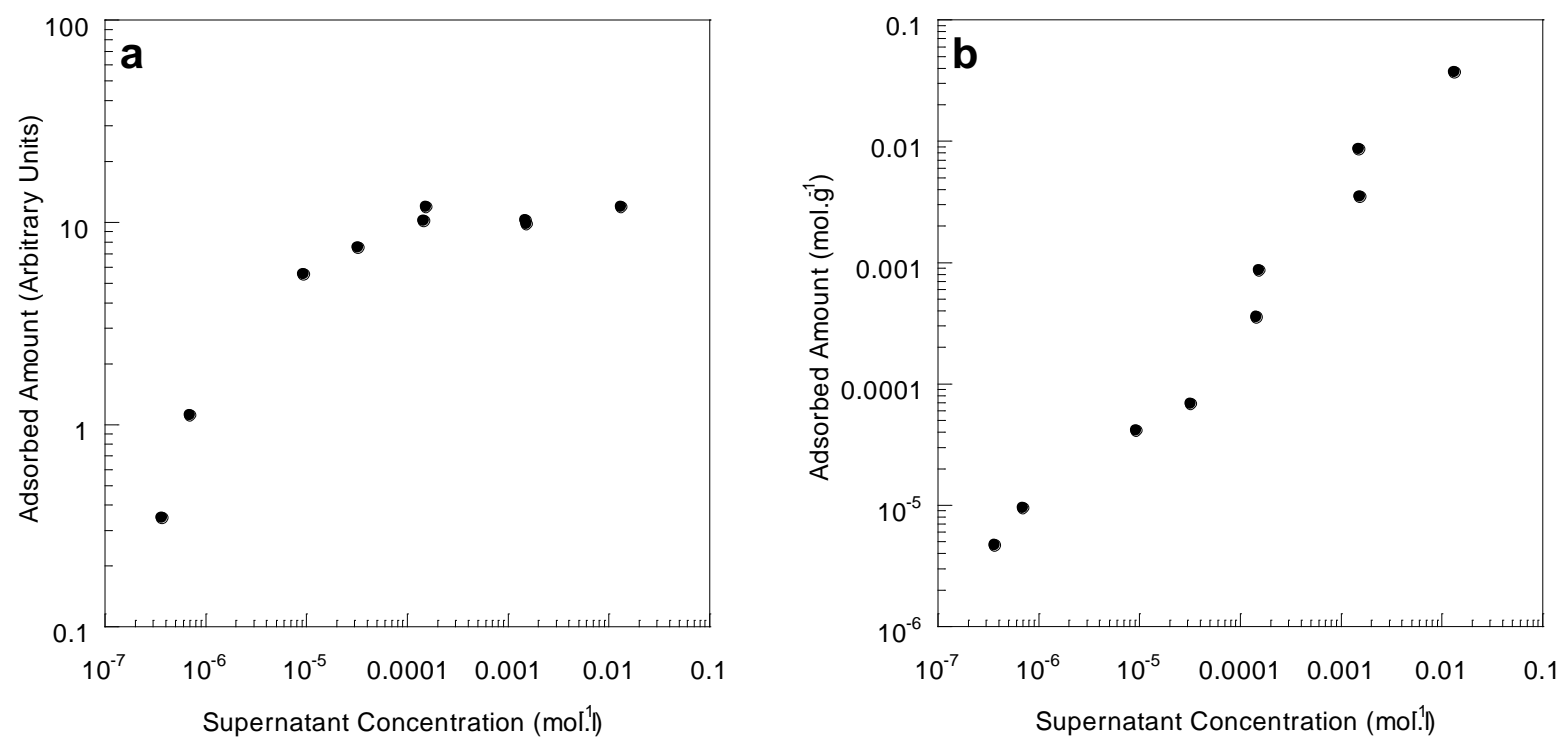

Figure 2. Adsorption isotherm of oleate on fluorite (a) adsorbed amount determined by diffuse reflectance infrared spectroscopy; (b) adsorbed amount determined by difference with the residual concentration measured by colorimetry.

Assessment of particle hydrophobicity. After flotation tests, the concentrations selected for fluorite and quartz coating with oleate and docecylamine chloride were $210^{-5} \mathrm{~mol} / \mathrm{g}$ and $210^{-6} \mathrm{~mol} / \mathrm{g}$, respectively. Figure 3 shows the relative percentages of floated particles, coated or not coated with surfactant. The Hallimond tube is a qualitative method and some entrainment of particles with bubbles always occurs. However, it is clear that the addition of surfactant significantly enhances the flotation of fluorite and quartz. As a consequence, particles of similar size distribution but varying surface characteristics (negatively charged quartz - dodecylamine coated quartz - positively charged fluorite -oleate coated fluorite) can be obtained.

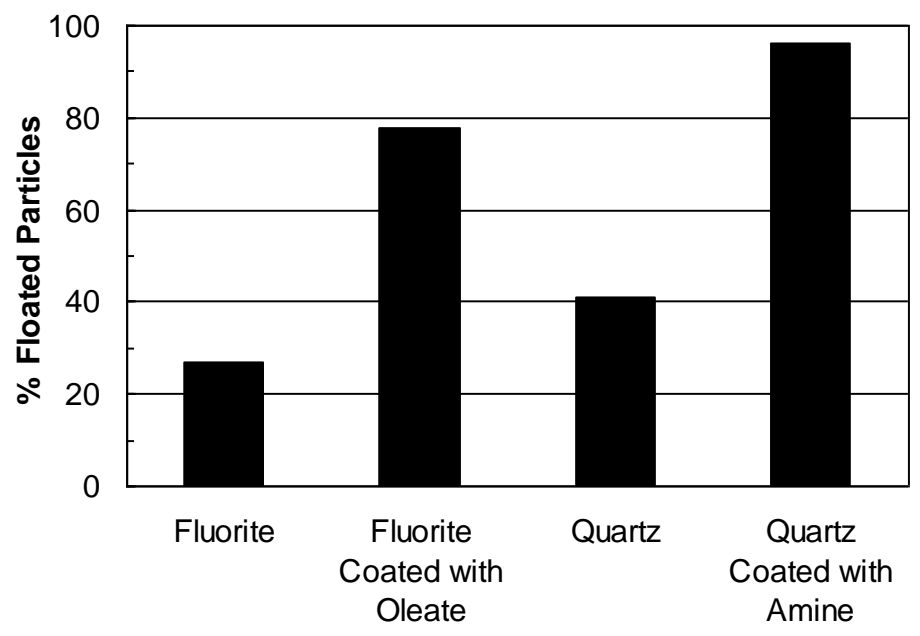

Figure 3. Relative percentages of floated particles determined by the Hallimond tube method.

Particle incorporation in activated sludge flocs. A previous study revealed that the incorporation of Aquatal particles within activated sludge flocs did not significantly modify the dynamics and structure of bacterial aggregates (Chaignon et al., 2002). As illustrated in figure 4, such 
observations can be repeated with sludges conditioned with fluorite and oleate coated fluorite. First, at constant stirrer speed $\left(100 \mathrm{rpm} / 135 \mathrm{~s}^{-1}\right)$, the temporal evolution of mean floc size is not affected by the addition to the sludge of fluorite or oleate coated fluorite particles. In particular, no further aggregation can be detected upon particle addition. Furthermore, upon submitting the sludge to a cyclic step change in agitation (stirrer speed increased to $300 \mathrm{rpm} / 600 \mathrm{~s}^{-1}$ for $8 \mathrm{~min}$ and then set back at $100 \mathrm{rpm}$ ), the ballasted flocs first break-up and then re-form when low agitation is restored, thus exhibiting an aggregation behavior similar to that of a raw sludge (Chaignon et al., 2002). In addition, Chaignon et al. (2002) reported that floc re-growth was facilitated upon incorporation of Aquatal particles, the added particles likely acting as nuclei during that stage. In our case, it appears that the re-formation of flocs spiked with oleate coated fluorite is facilitated, thus suggesting that those particles are better incorporated within flocs. Floc size measurements also indicate that neither the addition of unadsorbed surfactant nor its sodium counter-ion deteroriate the floc dynamics. Residual oleate is likely adsorbed on activated sludge aggregates (Urano and Saito, 1984), while the amount of sodium ion added $\left(510^{-4} \mathrm{~mol} / \mathrm{L}\right)$ is certainly too low to alter floc size (Bruus et al., 1992). Finally, even if fluorite particles and microbial flocs are oppositely charged, fluorite addition does not appear to induce any heteroaggregation.

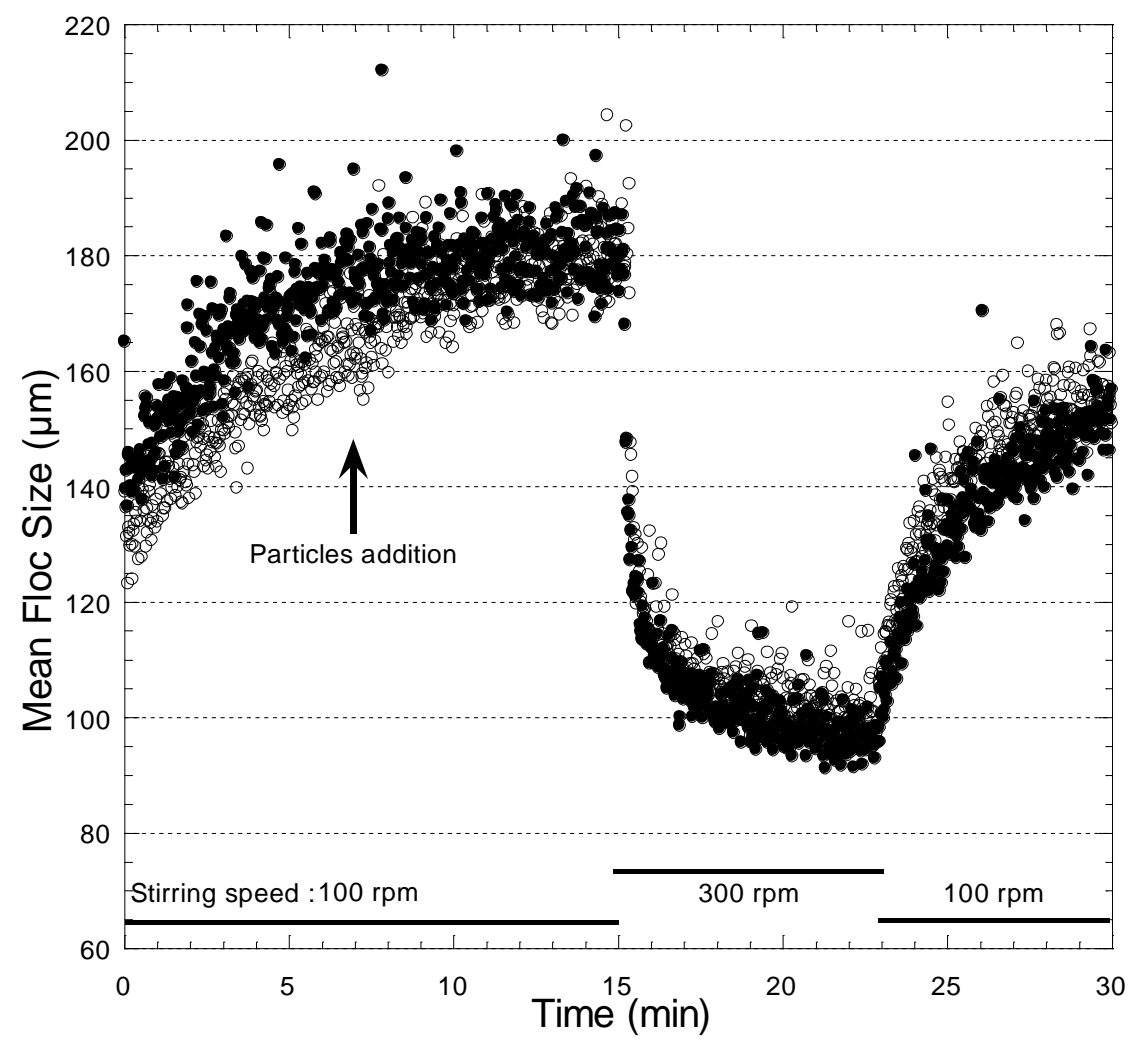

Figure 4. Variation of average floc size as a function of time upon addition of particles and during a cyclic step change in agitation intensity. ( $\boldsymbol{(})$ oleate coated fluorite; $(\bullet)$ fluorite.

The association of coated and non-coated particles with activated sludge flocs was assessed by optical microscopy. Between crossed polarizer and analyzer, an increase in incorporated particles implies a decrease in the exposure time required to take a micrograph. Figures $5 \mathrm{a}$ and $5 \mathrm{~b}$ compare the cumulative frequency curves of exposure times obtained with: (a) raw activated sludge / sludge+fluorite / sludge+oleate coated fluorite, and (b) raw activated sludge / sludge+quartz / sludge+dodecylamine coated quartz. The raw activated sludge naturally contains particles originating both from human activity (alloys, pigments,...) and neoformation of mineral phases within the sewer system (metal sulfides, phosphates,...) (El Samrani et al., submitted). Nevertheless, 
the addition of supplementary particles to the sludge always shifts the distribution of exposure times towards smaller values, this shift being significantly reinforced when the particles are made hydrophobic. The surface charge of particles does not seem to strongly influence the association process as non-coated quartz and fluorite are incorporated within microbial flocs to a similar extent. Figure 5c compares the incorporation of Aquatal, oleate coated fluorite, and fluorite, in activated sludge flocs. In that case, the curve corresponding to hydrophobic fluorite is nearly superimposed with that determined for Aquatal, which suggests that hydrophobized particles may represent an alternative to the commercial product.

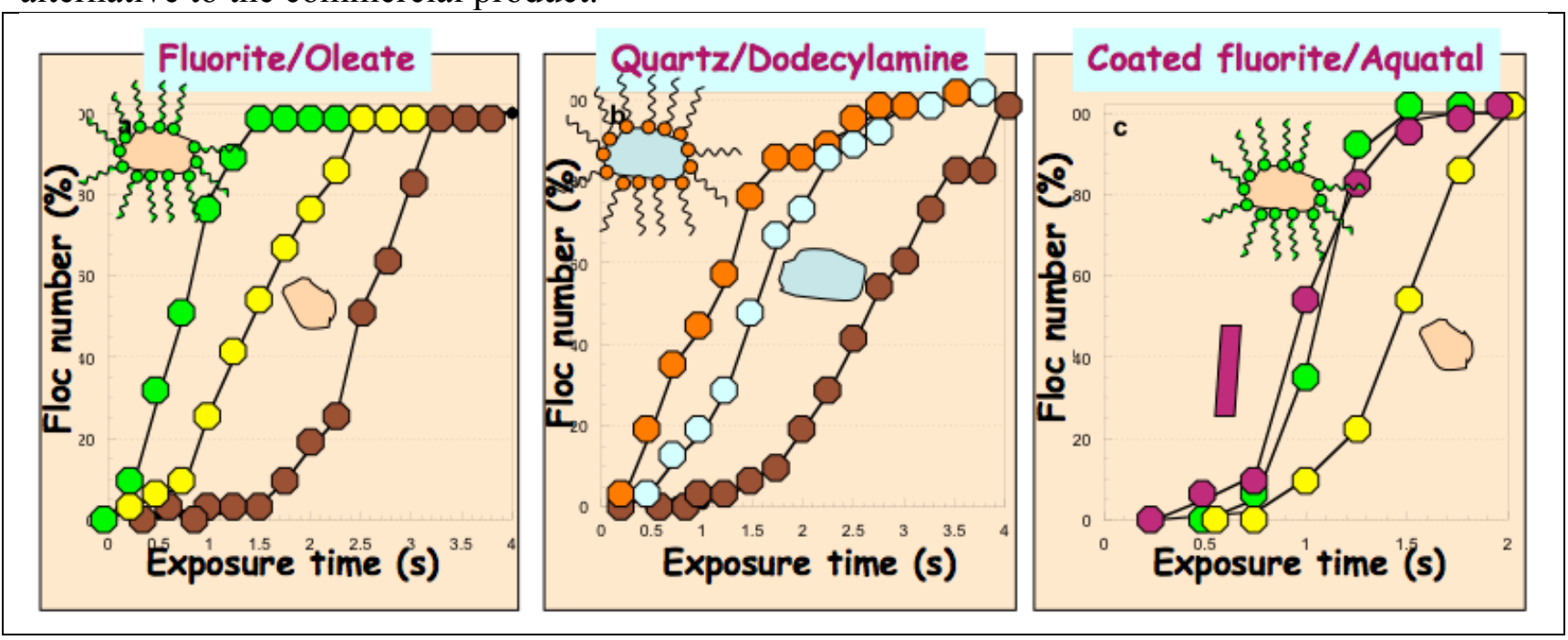

Figure 5. Cumulative frequency curves of exposure times for: (a) oleate coated fluorite $(\bullet)$, fluorite $\left({ }^{\circ}\right)$, and raw sludge $\left({ }^{\bullet}\right)$; (b) dodecylamine coated quartz $\left(^{\bullet}\right)$, quartz $\left(^{\bullet}\right)$, and raw sludge $\left(^{\bullet}\right)$; (c) Aquatal $\left({ }^{\bullet}\right)$, oleate coated fluorite $\left({ }^{\bullet}\right)$, fluorite $\left({ }^{\bullet}\right)$.

\section{CONCLUSION}

The results reported in this study were repeated in triplicate on sludges from the same wastewater treatment plant. An enhanced incorporation of hydrophobized particles was systematically observed which strongly suggests that hydrophobic patches are present in activated sludge flocs. A detailed study on the spatial distribution of these patches could then be carried out using the approach developped in this study. In addition, similar procedures could also be extended to other clarification processes using mineral particles as floc ballasting agents (Desjardins et al., 2002).

\section{Acknowledgments}

The authors would like to thank the Grand Nancy urban community for sampling authorization, the staff of Maxéville wastewater treatment plant for experimental assistance, and Luzenac Europe for providing a sample of Aquatal.

\section{REFERENCES}

Bruus J.H., Nielsen P.H. and Keiding K. (1992). On the stability of activated sludge flocs with implications to dewatering. Wat. Res. 26, 1597-1604.

Chaignon V., Lartiges B.S., El Samrani A.G., Mustin C. (2002). Evolution of size distribution and transfer of mineral particles between flocs in activated sludges: an insight into floc exchange dynamics. Wat. Res. 36, 676-684.

Desjardins C., Koudjonou B. and Desjardins R. (2002). Laboratory study of ballasted flocculation. Wat. Res. 36, 744-754. 
Doerler N. (1982). Influence du broyage sur les propriétés massiques et superficielles du quartz et de la biotite. Conséquences sur l'adsorption de tensio-actifs ioniques. PhD Thesis, University of Nancy (INPL), France.

El Samrani A.G., Lartiges B.S., J. Ghanbaja, J. Yvon and A. Kohler. Trace element carriers in combined sewer during dry and wet weather: an electron microscope investigation. Wat. Res., submitted.

Free M.L. and Miller J.D. (1996). The significance of collector colloid adsorption phenomena in the fluorite/oleate flotation system as revealed by FTIR and solution chemistry analysis. Int. J. Miner. Process. 48, 197-216.

Gregory G.R.E.C. (1966). The determination of residual anionic surface active reagents in mineral flotation liquors. Analyst, 91, 251-257.

Piirtola L., Hultman B., Andersson C. and Lundeberg Y. (1999). Activated sludge ballasting in batch tests. Wat. Res., 33(8), 1799-1804.

Mielczarski J.A., Mielczarski E. and Cases J.M. (1999). Dynamics of fluorite-Oleate interactions. Langmuir, 15(2), 500-508.

Mielczarski E., de Donato Ph., Mielczarski J.A., Cases J.M., Barres O. and Bouquet E. (2000). Solution chemistry in adsorption layer formation of oleate on fluorite. J. Colloid Interface Sci. 226, 269-276.

Olofsson A.C., Zita A. and Hermansson M. (1998). Floc stability and adhesion of greenfluorescent-protein-marked bacteria to flocs in activated sludge. Microbiol. 144, 519-528.

Rasmussen M.R., Larsen T. and Clauss F. (1996). Improving settling dynamics of activated sludge by adding fine talc powder. Wat. Sci. Technol. 34(5-6), 11-18.

Urano K. and Saito M. (1984). Adsorption of surfactants on microbiologies. Chemosphere, 13(2), 285-292.

Urbain V., Block J.C. and Manem J. (1993). Bioflocculation in activated sludge: an analytic approach. Wat. Res. 27(5), 829-838.

Vanderhasselt A. and Verstraete W. (1999). Short-term effects of additives on sludge sedimentation characteristics. Wat. Res. 33(2), 381-390.

Zita A. and Hermansson (1997). Effects of bacterial cell surface structures and hydrophobicity on attachment to activated sludge flocs. Appl. Environ. Microbiol. 63(3), 1168-1170. 